\title{
Exposure as Collected Mood
}

National Cancer Institute

\section{Source}

National Cancer Institute. Exposure as Collected Mood. NCI Thesaurus. Code C117474.

A description of the mood of the collected exposure record. 